\title{
A genética do câncer de mama e a pluripotência do gênero
}

\author{
BRCA genes and the 'pluripotency' of gender'
}

Sahra Gibbon ${ }^{2}$

\begin{abstract}
Resumo
A chamada revolução genética, o progresso das ciências do ser vivo e o crescimento da medicina preditiva, estimulou a pesquisa social não penas a examinar as recentes formas de saúde e identidade trazidas à tona por essa conjectura, mas também tem recentemente se envolvido em esforços para examinar a quanto tempo categorias culturais de diferença e identidade, como raça e etnia, podem receber um novo olhar através do desenvolvimento de um novo conhecimento genético e tecnológico. Gênero é analisado como uma categoria de diferença de igual importância, que também é renovado pelos desenvolvimentos dentro da genômica. Nesse artigo analisarei essas questões em relação a essa área específica da ciência genômica e a medicina, focando no domínio conhecido como "genética do câncer de mama". Os progressos analisados nesse artigo podem ser complementados se examinados sob a noção de pluripotência referindo-se a forma múltipla e dinâmica através das quais o gênero feminino tem se estruturado, sido centro para si mesmo, e as vezes sendo transformado em relação ao campo do conhecimento e tecnologia associados aos genes do Câncer de Mama.
\end{abstract}

Palavras-chave: Genética. Gênero. Saúde. Câncer de Mama. Identidade.

\section{Abstract}

The so-called genetic revolution, developments in the life sciences and the rise of predictive medicine has stimulated social research not only to examine the novel forms of health and identity brought about at these junctures, but has also more recently involved efforts to examine how 'older' cultural categories of difference and identity such as race and ethnicity might be given new life by the development of new genetic knowledge and technologies. Gender must be regarded as an equally important category of difference that is also being informed by developments in genomics. In this paper I will examine these questions in relation to this particular area of genomic science and medicine by focusing on a domain known commonly as 'breast cancer genetics'. The developments explored in this paper can be usefully examined in the light of the notion of 'pluripotency' in referring to the diverse and dynamic modes through which female gender has informed, been central to and itself

\footnotetext{
1 Nota dos editores:

The publisher and editors of the Yearbook of Women's History give permission to re-publish the following article in the jornal Cadernos de Pesquisa em Ciências Humanas. Os Editores do "Yearbook of Women's History" autorizam a republicação desse artigo no periódico Cadernos de Pesquisa Interdisciplinar em Ciências Humanas.

${ }^{2}$ Membro do University College London, departamento de Antropologia. E-mail: s.gibbon@ucl.ac.uk
}

Esta obra foi licenciada com uma Licença Creative Commons - Atribuição 3.0 Não Adaptada 
sometimes been transformed in relation to the field of knowledge and technology associated with the BRCA genes.

Keywords: Genetics. Gender. Health. Breast cancer. Identity.

The so-called genetic revolution, developments in the life sciences and the rise of predictive medicine has stimulated social research not only to examine the novel forms of health and identity brought about at these junctures, but has also more recently involved efforts to examine how 'older' cultural categories of difference and identity such as race and ethnicity might be given new life by the development of new genetic knowledge and technologies (DUSTER, 1990; MONTOYA, 2007; FULLWILEY, 2007). Gender must be regarded as an equally important category of difference that is also being informed by developments in genomics. Yet while questions of gender have been at the forefront of research examining the way that women are subject to and recruited into new reproductive technologies and the way that these techniques simultaneously naturalize and de-naturalize gender, reproduction and the biological, the dynamics between genes and gender in relation to predictive genomic interventions has received less attention (RAPP, 1999; STRATHERN, 1992; FRANKLIN, ROBERTS, 2006). In this paper I will examine these questions in relation to this particular area of genomic science and medicine by focusing on a domain known commonly as 'breast cancer genetics'. This emerging and fast growing area of genomic medicine is linked to the discovery and application of the knowledge and technologies associated with two inherited susceptibility genes BRCA1 and BRCA2. These genes were identified in the mid-1990s, and are thought to confer an increased risk of developing the disease and are thought to account for between 5 and 10 percent of all breast cancers. Genetic testing and identification of those at increased genetic risk of developing breast cancer, as a result of carrying a mutated copy of one of these genes, have formed the basis of an expanding domain of genetic medicine in the United Kingdom, Europe, United States, Canada and elsewhere recruiting thou-sands of healthy but 'at risk' women (and smaller numbers 
of men also) into new arenas of health care. ${ }^{3}$ Even as such developments must be understood as forming part of the particular history of biomedicine (SCHUNDLER, 2014), as a number of social scientists have already suggested, this is an arena where the hype and hope-filled predictive and preventative promise of genetics is highly visible (GIBBON, 2007; GIBBON et al., 2010; GIBBON et al., 2013; HAPPE, 2013; PALFNER, 2009; KAMPRIANI, 2009; MOZERSKY, JOSEPH, 2010).

Examining the emergence of this field of knowledge in the late 1990s in the United Kingdom, I argued that the rapid translation of techniques for identifying genetic risk into cancer genetic services and clinical interventions had to be understood in relation to certain kind of 'gendering' (GIBBON, 2007; GIBBON, NOVAS, 2008). I used the concept of gendering to point to both the productivity and tensions in the meeting points between female health activism around breast cancer and the hype and hope-filled prospect of predictive genetics and personalized medicine that BRCA genetics came to and to some extent still symbolizes. Drawing on concepts of 'co-production' and 'biosociality' I argued that a culture of gendered health activism, which simultaneously valorized notions of women's collective and individual 'rights and choice' and the naturalization of female nurturance, were productively mobilized across different institutional arenas at the meeting point between patients, families, practitioner, activist and fundraising communities caught up with an emerging domain of BRCA genetics (JASANOFF, 2006; RABINOW, 1996).

The ongoing saliency of these gendered moralities and values have been particularly apparent recently in the global media storm that has surrounded the coverage of Angelina Jolie's announcement in the New York Times that she had had a prophylactic mastectomy after testing positive for a mutation on the BRCA1 gene in May 2013 (JOLIE, 2013). The justification for her decision in her public announcement was openly framed in terms of the personal loss of her own mother to

\footnotetext{
${ }^{3} \mathrm{I}$ do not explicitly consider the question of BRCA genes and male gender in this article. But it is nevertheless important to note that a very small number of men also develop breast cancer in the United Kingdom and elsewhere every year. Men can be carriers of the BRCA genes also without necessarily developing breast cancer and of course men may have a significant role in decision making in the family regarding testing. See for instance: N. Hallowell et al., 'Men's decision making about predictive BRCA1/2 testing. The role of the family', Journal of Genetic Counseling 14 (2005) 3, 207-217.
} 
the disease and her desire to tell her children that as she said 'they don't have to fear they will lose me to breast cancer'. Jolie also described the decision in terms of being personally 'empowered' and helping other women 'to know you have options'. It was an announcement that powerfully aligned affective and value laden discourse about mothering and women's individual and collective rights and choices to know about and undertake such interventions.

That a highly public celebrity, whose physical appearance has been frequently vaunted across a global media stage, had decide to surgically remove her breasts as a preventative measure, generated a highly polemical discussion across a range of social and public media across a global arena. Diverse opinions were reflected which both vehemently supported and in some cases critiqued Jolie's actions and her decision to publically announce on them. Some drew attention to her personal bravery and courage, situating her decision in terms of empowering other women and highlighting the currently restricted access to testing services or the prohibitive cost of genetic testing and surgical interventions. Others however raised concerns about the kind of message such a public announcement might send about the risks of breast cancer when only a relatively small number of cases of breast cancer are linked to genetic mutations, and that her actions might imply that having a gene mutation necessarily meant developing breast cancer or that the only solution would be prophylactic surgery. It is too soon to perhaps assess the full social and cultural repercussions of her announcement but it is interesting to note that in the months following this, the Supreme Court in the United States has ruled against the patenting of human genes effectively ending the monopoly that one United States company (Myriad Genetics) had on offering predictive genetic testing for the BRCA genes (ZIMMERMAN, 2014).

There have also been decisions in the United Kingdom and elsewhere to expand genetic testing and drug intervention for women with a family history of breast cancer, that have made explicit reference to Jolie's public announcement. ${ }^{4}$ While clearly difficult to attribute direct causation between these events it is interesting to see how they have unfolded virtually simultaneously with likely

\footnotetext{
${ }^{4}$ See for instance 'Breast cancer gene test extended in Scotland' on www.bbcnews/uk-scot-land22598491.
} 
significant impacts across diverse social and policy spheres within different national arenas (GIBBON, 2014). What is more certain is that the affective and moral framings of motherhood and women's choice and rights to genetic testing by one high profile female celebrity caught up in the world of BRCA testing have created a powerful advocate for this field of medicine. As a result the already 'iconic' figure of the BRCA carrier has been personified in highly gendered ways on a global scale reflecting and in turn informing the legitimacy of the turn to self-monitoring and health surveillance that has become a prominent feature of health care in many cultural contexts in Europe, Canada and the United States.

In recent years social scientists examining developments in BRCA genetics have explored how in fact a range of gendered idioms have become central to the knowledge and technologies that surround genetic interventions associated with these genes (HALLOWELL, 2005; GIBBON, 2007; HAPPE, 2006; PELTERS, 2014). Collectively these scholars have been concerned with how ideas of female nurturance, motherhood, biologized sex differences as well as how a discourse of female empowerment, choice and rights have become instrumental to the translation of BRCA genetics into clinical care and how technologies and knowledge associated with these genes can contribute to the reproduction and sometimes transformation of gendered norms across different comparative and global arenas of health. However, the gendering of genetics is not a straightforward process. As Ettore et al. argue, when examining the interface between gender and genes the challenge is to 'effectively account for not only the complex and contingent politics of women in respect of genetics, but for the complex attachments, intersubjective relations and forms of alienation that might be at play' (ETTORE et al., 2006).

In this article, building on my ethnographic work in breast cancer genetics, I reflect on the dynamic and shifting relationship between gender and genes and the powerful ways that these are co-configured. I will explore whether and to what extent the new technological field that is BRCA genetics is reproducing gendered cultural norms with respect to for instance motherhood and family care or/and enabling or creating new gendered norms configured through a discourse of empowerment or choice. In this sense I will also explore whether a dichotomy between continuity and discontinuity or traditional and modern is sufficient in examining the interface of gender and genetics in the context of BRCA (see PLATES XV-XVII). 


\section{Mothering, responsibility and the reproduction of gendered norms}

In her work on reproductive technologies Rapp has shown how questions of female responsibility are situated in the clinical setting and beyond. Following Rapp's work other authors have highlighted the question of responsibility and how women are particularly subject to the 'benefits and burdens' of the knowledge and technologies for identifying genetic risk associated with breast cancer (HALLOWELL, 1999; D'AGINCOURT-CANNING, 2001; LEMKE, 2005). D'Agincourt Canning early on noted the dangers associated with the disclosure of genetic information linked to an increased risk of breast cancer within a given family showing how gendered patterns of socialization may obligate women to feel morally responsible to share information with mothers, sisters and other family members and thereby recruiting them into genetic clinics and predictive interventions (D'AGINCOURT-CANNING, 2001). As the primary receivers of genetic information women are particularly susceptible to the powerful promises of predictive knowledge and preventative health that genetic interventions such as genetic testing bring forth, not just in terms of care for oneself but also for related others. Here the appeals to and discourses of motherhood are particularly prominent and many women in their stated justifications to undergo genetic testing frame such decisions in terms of acting 'for their children'.

Other ways of framing normative gendered notions of female gender in the context of development in BRCA genetics have been foregrounded by Kelly Happe and Britte Pelters. (HAPPE, 2006; HAPPE, 2013; PELTERS, 2014). Happe argues it is the 'legacy of gender bias' in health care and medicine and the dependency on naturalized understandings of gender and the body which must be the overarching concern for feminists concerned about the discourse of individualized risk that has emerged in relation to BRCA genetics. In understanding how women's bodies are disciplined in 'normative ways' related to reproduction and motherhood, she has been particularly concerned with the growing use of prophylactic oophorectomy (surgical removal of ovaries) as a preventative intervention for those identified as BRCA carriers.

Such interventions are she suggests especially significant in a context where these procedures have been otherwise problematized from a medical and clinical 
perspective. She persuasively argues that the 'exceptionalism' of such interventions for those identified as carrying a mutation on one of the BRCA genes is achieved through a routinization of gendered subjectivity. Here she argues an 'ideology of femininity' operates 'which reduces ovaries to their reproductive function', such that an older frame of gender bias in biomedicine has, in the context of BRCA has created a 'new rational discourse of diseasing women's reproductive organs' (HAPPE, 2013).

The prominence of normative understandings of femininity in the context of BRCA genetics are also more directly explored by Britte Pelters (PELTERS, 2014). She examines how organs such as ovaries and breasts are linked to the cultural construction of femininity and norms of gender functionality, and shows how stereotypes of female nurturance and tropes of breast 'loss' and 'restoration' inform the medical discourse related to BRCA screening and prophylactic surgery. For example, she suggests that medical texts describing the physical effects of prophylactic surgeries for those carrying a mutation on one of the two BRCA genes are presented in terms of a 'diminishing' of femininity and sexuality reflecting, she argues, a 'biomedical norm of gender functionality' (ibidem). Yet she also provocatively asks whether, given the prominence of post-structuralist understandings of the relationship between sex and gender, being BRCA positive and preventive surgery might not also form the basis for transgressing norms of gendered femininity given, as she puts it, their 'queering potential'. In this context it is interesting to consider the extent to which Angelina Jolie's actions to have prophylactic surgery and reconstruction can be considered as transgressing or reiteration of gendered norms, when she publically states that the result of such surgery 'can be beautiful'.

Kelly Happe acknowledges that the plausibility of prophylactic surgeries to reduce genetic risk is directly related to the success of feminist efforts to separate reproduction from the female body, noting also that the field of BRCA medicine is 'replete with messages about empowerment' (HAPPE, 2013). Yet her work nevertheless suggests that the on-going effects of the normative disciplining of women's bodies in the era of BRCA genetics is what needs to be accounted for. She sees the emergence of this novel field of medicine as part of the production of 'gendered bio-capital' and calls for greater attention to the 'continuities' at stake in Cad. de Pesq. Interdisc. em Ci-s. Hum-s., Florianópolis, ISSN 1984-8951 
these developments, critiquing claims to novelty in the 'biosocial' configurations of gendered subjectivity and identity surrounding BRCA genetics.

\section{Activism, rights and the scope/limits of BRCA biosocialities}

Yet it is in fact just such transformations in citizenship and gendered subjectivities which have been the focus of a number of social scientists keen to explore the range of what have been described as 'biosocialities' that are emerging at the interface with various aspects of genomics in the United States, Europe and elsewhere (GIBBON, NOVAS, 2008; RABINOW, 1996). In the context of BRCA genetics we see how continuities in gendered frames of reference are being informed by new configurations of identity, activism and citizenship which in the global arena in which breast cancer genetics now operates within suggest neither homogenizing transformation nor stasis but in fact can bring about uneven effects and unexpected consequences.

Earlier work has highlighted how local cultures of breast cancer activism are informing or themselves being informed by genetic knowledge such that efforts to expand BRCA testing services are often framed in terms of women's 'choice' and 'rights'. (GIBBON, 2007; KLAWITER, 2008). Here I provide three further illustrative examples that demonstrate the ongoing productivity of the interface between gendered health activism and the BRCA genes.

This meeting point is nowhere more apparent than in the emergence of the identity concept associated with healthy women identified as having a BRCA mutation in terms of being 'previvors'. Defined in terms of 'survivors of a predisposition to cancer' this identity concept is linked to a domain of practice and discourse which is increasingly being mobilized by certain activist communities particularly in the United States, such as FORCE (Facing Our Risk of Cancer Empowered). ${ }^{5}$ These mainly online communities are dedicated to supporting those who are identified as being at genetic risk for breast cancer and actively lobbying for resources and research on and about those who are increased risk of breast cancer

\footnotetext{
${ }^{5}$ See www.facingourisk.org.
} 
because of a mutation on their BRCA genes. As Bell points out such developments must be seen in terms of a wider field of transformation around the concept of 'the cancer survivor'. With the case of BRCA, the 'teachable moment' of survivorship is shifted further back to the discovery not of disease but of risk such that BRCA increasingly acts as a 'trope' for disease (BELL, 2012).

In this way survivorship is now ascribed to women who have not had cancer but following a genetic test and are now living with the risk of developing breast cancer as a consequence of a positive result. Exploring this expanded domain of activism in relation to BRCA genetics in the United States in a second example Sandra Lee's work examines how notions of 'freedom' and 'empowerment' became linked to the expanding market of direct to consumer testing by commercial genetic testing companies such as 23andMe now offering BRCA screening (LEE, 2014). As Lee implies in her discussion this raises new questions about the benefits and burdens of gendered regimes of personalized medicine in the United States.

Other social scientists have drawn attention to how issues of empowerment have been mobilized around a focus on the 'underserved' needs of women in specific identified population groups, such as African Americans or Latinos in the United States, as they have become the target of BRCA screening interventions. This reflects a wider set of developments explored in the United States where a discourse of rights and social justice has increasingly become tethered to genomic research, the pursuit of personal medicine and genetic therapeutics (LEE, 2008). Galen Joseph's work focuses on the intersection of BRCA research and clinical practices and the biopolitics of health disparities in the United States where a focus on 'embodied difference' in biomedical clinical research has become normalized (JOSEPH, 2014; EPSTEIN, 2007). Drawing on research examining health promotion programs lined to extending BRCA services, including genetic testing in African American churches, Joseph illustrates how attempts to 'biosocialize' participants in terms of offering 'at risk' identity is over determined for many female participants by the long history and experience of inequities and discrimination in health care. For example participants, through their involvement in community health projects to identify their risk through a focus on family history, are offered, Joseph argues, a discourse of empowerment and responsibility. Nevertheless for African American Cad. de Pesq. Interdisc. em Ci-s. Hum-s., Florianópolis, ISSN 1984-8951 v.15, n.107, p. 137-157, ago/dez 2014 
women recruited into these initiatives there is a focus on other collective and less individualizing histories of discrimination and inequalities in health care and beyond. As a result Joseph suggests that the kind of preventive, anticipatory identity BRCA genetics requires, may not be sought or valued in quite the same way by the participants of these programs as it has in other sections of United States society. In this way her work points to the limits of particular idioms of individual 'risk, rights and choice' for differently situated activist communities.

While the first two examples suggest that there is ongoing and novel productivity at the interface between gendered health activism and the BRCA genes this final example suggests that the mobilization of interest and engagement with BRCA genes through an idiom of female empowerment is not always enabling and must be under-stood in relation to diverse histories and politics of race, gender and health care.

\section{BRCA between different modernities; transnational translations and transformations}

Comparative ethnographic studies examining the variable and disjunctured ways that BRCA genetics has being taken up in different clinical and social arenas suggest that there are in fact highly complex dynamics at stake in the way that specific gendered idioms operate in and sometimes against this emerging domain of genetic health care that challenge any simple dichotomy between novelty/continuity or tradition/modernity.

Eirini Kampriani's work on the implementation of BRCA testing in Greece, Alison Macdonald's work on breast cancer in India and some recent work I undertook in Cuba all illustrate in different ways how preventative interventions, orientated more or less explicitly around family history or breast cancer genetics, are mobilized and interact with traditional ideas of relational femininity or motherhood and the uncertainness of emerging what might be seen as postmodern gendered roles (GORDON, 2014). ${ }^{6}$ In Cuba the tension between these different dynamics while

\footnotetext{
${ }^{6}$ See also: D. Gordon, 'It takes a Particular World to Produce and Enact BRCA Testing; The US had it, Italy had Another', in: Gibbon et al. (eds.), Breast Cancer Gene Research.
} 
present remains somewhat hidden and latent. My research examining perceptions and beliefs about risk of breast cancer in Cuba among differently situated publics suggests that it is in part overshadowed by a long standing history in Cuba of socialist collective public health interventions. Here the state organization of health care very directly colours perception of disease aetiology in ways that support the notion of family history being a risk factor for the disease. But there is also as a result less perception of individual responsibility as this relates to disease risk such that genetic explanations for disease causation are supplanted for many women by an idea that breast cancer risk is related to a physical 'blow' or factors in the environment (GIBBON, 2009). Nevertheless, a nascent discourse of 'risk' and 'rights' related to the possibility of having a genetic test, is apparent in the individual narratives of Cuban women in certain areas of the country, where for example individual women may be in contact with wealthy relatives in Miami have pursued or sought out such interventions. The tension between traditional or fixity what might be seen as more postmodern or neoliberal ideas about gender roles becomes more explicit in Alison Macdonald's work examining the activities of breast cancer patient organizations in India. Her research suggests that there is an explicit 'subordination' of BRCA genetic knowledge in India where there is very little institutional interest or personal concern about genetic testing. Nevertheless attending to 'risk', including that associated with family history, is in India constituted through a discourse about modernity and temporality that reflect and inform changes in women's livelihoods. For example, the increasing age of marriage of Indian women is seen as problematic symptom of such change which is discursively implicated in an emergent discourse of breast cancer risk and prevention. As Macdonald points out, increasing attention therefore to family history as a risk for breast cancer 're-inscribes particular patterns of gendered practice in complex and novel ways' (MACDONALD, 2014).

By comparison, Kampriani's work examining the specific context of BRCA genetic testing in rural Greece shows how these tensions emerge in relation to religious philanthropic organizations targeted focus on the underserved needs of rural women. She illustrates how in this context a 'cultural ethics of protection', which sees these women as deprived and traditional, is linked to a modernist gendered discourse of rights and choice in making BRCA testing services available to them which unevenly facilitates this fledgling domain of health care in Greece Cad. de Pesq. Interdisc. em Ci-s. Hum-s., Florianópolis, ISSN 1984-8951 v.15, n.107, p. 137-157, ago/dez 2014 
(KAMPRIANI, 2014).

In all these cases it would be hard to suggest that uniform pre-existing gendered norms are simply being stabilized or even homogenously transformed in the widening global transnational arena of BRCA genetic research and medicine. Expanding on this point in a co-authored article in the special edition of the Journal of Biosocieties comparing BRCA genomics across three different national contexts I and my co-authors point out that the expansion of BRCA testing cannot be seen as either a kind of globalizing novel form of biosociality, any more than it can be seen as simply as the reiteration or materialization of traditional gendered inequalities and norms (GIBBON et al., 2010). We suggest instead that the reproduction of seemingly neo-liberal forms of BRCA subjectivity which emphasize individual autonomy, choice and control is never uniform but in fact discontinuous and disjunctured. Moreover we show how across three national domains of practice (Cuba, Greece and Germany) the transnational expansion of the field of BRCA genetics is necessarily informed and shaped by different discourses of gender identity and particular institutional health care cultures, with their own histories and moralities of health prevention.

\section{Postgenomics and BRCA - epigenetics and gender}

Even as BRCA testing becomes part of an expanded domain of predictive medicine across different aspects of public and private health care in the United Kingdom, Europe and elsewhere, there are ongoing questions and debates about the meaning and significance of different mutations or how to define genetic risk for different populations (MOZERSKY, JOSEPH, 2010; MOZERSKY, GIBBON, 2014). Yet at the same time BRCA genetics is entering other novel arenas of research and health care. There is for instance now the possibility of using BRCA testing within the context of Pre-implantation Genetic Diagnosis to screen embryos for the BRCA genes prior to IVF treatment (RUBIN, MELO-MARTIN, 2014). There is also the widening use of research on the BRCA genes for not only those who carry a mutated copy of BRCA in their germline but for the treatment of those with sporadic breast cancer through tumour testing and profiling of those currently affected by the disease in efforts to develop better treatment options (BOURRET et al., 2014). These Cad. de Pesq. Interdisc. em Ci-s. Hum-s., Florianópolis, ISSN 1984-8951 
developments are shifting the parameters of understanding and the scope of medical interventions in the post-genomic arena of BRCA and cancer genetic research more generally that will likely have significant implications for how gender and questions of individual and collective responsibility for health, disease, prevention and treatment are conceived and acted upon. This is nowhere more apparent than in the field of epigenetics.

Epigenetics is one emerging domain of postgenomic research and health care intervention defined as an area of science related to understanding changes in gene expression not caused by molecular DNA, many of which are increasingly shown nevertheless to be heritable. Dramatically undermining the notion of the 'gene for', new so called 'epigenetic' paradigms for understanding disease risk and aetiology, suggest a much more 'plastic biology' with markedly less deterministic understandings of the relationship between bodies, health and environments (LANDECKER, 2011; LANDECKER, PANOFSKY, 2013).

In this final part of the paper I reflect on some of the new possibilities and dangers in the way that gender is becoming folded into as well as productive of complex epigenetic models of biological function and disease etiology as new understandings emerge of the relationship between society, culture and biology. Here there is the possibility of new 'biopolitical' paradigms for understanding conditions such as breast cancer which have the potential to examine disease aetiology through a frame of reference that includes genomics and environmental toxins. At the same time such research is linked to the danger of new forms of 'somatic determinism' that may potentially serve to reinforce cultural as well as gender stereotypes (NIEWÖHNER, 2011; LOCK, 2013).

Landecker and Padofsky point out that what is significant about emerging epigenetic paradigms of scientific understanding, is the way such discoveries resituate the temporal frame of disease aetiology and treatment interventions by identifying 'critical windows' when specific cells or bodies are considered vulnerable and susceptible (LANDECKER, PANOFSKY, 2013). Pointing to the liberatory potential of such new understandings they state:

there is a clear opening here for connecting expertise in the political economy of industrial regulation, the socioeconomic stratification of pollutant exposures due to housing and employment patterns, and the cultures of 
nutrition and self-care to the embedding and biological expression of those exposures (LANDECKER, PANOFSKY, p. 347).

This is what makes epigenetic research, related to environmental determinants of gene function, of particular relevance to understanding the influence of health inequities, including those related to gender. But as they also point out many of the 'critical windows' being examined in this emerging domain of genetic research relate to practices of early childhood, maternal-fetal health exposures including nutrition. As such epigenetic research has the potential to bring about new forms of what Niewöhner describes as 'somatic sociality' that could 're-sediment maternal blame' as regulatory interventions focus on the control and responsibility of individual behavior, particularly pregnant women (NIEWÖHNER, 2011; LANDECKER, PANOFSKY, 2013). ${ }^{7}$

The work of Rebecca Mansfield offers a salutary lesson about the dangers at stake in new epigenetic understanding for reproducing and sustaining older forms of cultural categorization such as race and gender (MANSFIELD, 2012). Examining the translation of epigenetic research into public health related to the effects of methyl mercury on fetal neurodevelopment she examines how this has led to United States regulatory agencies issuing advice relating to fish consumption to women of childbearing age. She argues that because of racial disparities in fish consumption, such efforts not only differentially impact women of colour but 'change the problem from contamination itself to the abnormal diets of these women' (idem, 352). This creates what she describes as an 'epigenetic biopolitics' in which the racialized reproductive woman's failure to 'make the right choices' is conceived as the problem to be solved rather than broader efforts to address the effects of environmental pollutants. Her work provides a timely reminder of the need for critical engagement, understanding and monitoring of how nascent epigenetic research is translated into public health and the gendered (and racialized) consequences of such interventions.

\section{Conclusion}

\footnotetext{
${ }^{7}$ See also: E. Yates-Doerr, 'Bodily betrayal. Love and anger in a time of epi-genetics', in: F. MasciaLees (ed.), A Companion to Anthropology of the Body and Embodiment (Malden MA 2011) 292-306.
} 
The notion of 'pluripotency' has been used more recently in the field of stem cell research to refer to the capability of certain stem cells to make many different cells, organs or tissues and specifically the ability of a stem cell to differentiate into many cell types. The developments explored in this paper can be usefully examined in the light of the notion of 'pluripotency' in referring to the diverse and dynamic modes through which female gender has informed, been central to and itself sometimes been transformed in relation to the field of knowledge and technology associated with the BRCA genes. It is a descriptor which attests to both the power of gendered practices and representations in the field of BRCA genetics but also the multivalent possibilities that the conjunction between genes and gender brings about.

Taking an overview of recent social science research this paper has examined how questions of responsibility and gendered norms of nurturance and reproduction are situated in the way BRCA technologies and interventions are implemented. At the same time it has examined how a discourse of female rights and choice has and continues to inform what might be seen as gendered biosocialities emerging at the interface between with these developments, where citizenship and risk are increasingly productively aligned. Jolie's recent highly public announcement of her decision to undertake a prophylactic mastectomy following a positive BRCA test illustrates the ongoing saliency of these different gendered norms where morality and affect become so powerfully combined.

At the same time, ethnographically informed social science research in local and transnational contexts points to the difficulty of situating the interface between BRCA and gender only in relation to these particular gendered norms of seeing gender and the BRCA genes. Equally insufficient are both static readings of these developments as continuities related to older ways of framing female gender or understandings that suggest the global spread of genetic techniques such as BRCA testing bring about homogenous transformations. Rather what we have seen in different ethnographic examples is how BRCA genes operate between, within and through transnational translations and transformations in which diverse gendered idioms in-form how a discourse of genetic risk and knowledge is positioned, understood and acted upon.

The final section of the paper examining how BRCA genes are entering other Cad. de Pesq. Interdisc. em Ci-s. Hum-s., Florianópolis, ISSN 1984-8951

v.15, n.107, p. 137-157, ago/dez 2014 
domains of health care and research beyond predictive genomics highlights how gender becomes positioned in newly potent ways in fields such as epigenetics where there are both new possibilities for configuring gendered responsibilities and the politics of health. Here the possibility of a new rapprochement between the collective politics of public health, epigenetic understanding of genes and environment and new attention to biological difference holds out hope, if not for a 'biosociality without genes' then at least one where the stakes of prevention and health could be positioned somewhat differently (HAPPE, 2006). Yet gendered responsibility remains central to these novel configurations and understandings of disease aetiology. An ever widening paradigm of epigenetic research focusing on the life course and 'critical windows' of intervention, such as maternal-fetal health, requires ongoing social science attentiveness, engagement and vigilance to the likely shape shifting dynamics between genes and gender. 


\section{References}

BELL, K. Remaking the self. Trauma, teachable moment and the biopolitics of cancer survivorship.Culture, Medicine and Psychiatry, 36, 4, pp. 584-600. 2012.

BOURRET, P., KEATING, P. and CAMBROSIO, A. From BRCA to BRCAness. Tales of Translational Research. In: Gibbon et al. (eds.), Breast Cancer Gene Research and Medical Practices. Transnational perspectives in the time of BRCA. London, 2014.

D'AGINCOURT-CANNING, L. Experiences of genetic risk. Disclosure and the gendering of responsibility. Bioethics 15, pp. 231-247. 2001.

DUSTER, T. Backdoor to Eugenics. New York, 1990.

EPSTEIN, S. Inclusion. The Politics of Difference in Medical Research. Chicago, 2007.

ETTORE, E., ROTHMAN, B. and Steinberg, D. Feminism confronts the genome. Introduction. New Genetics and Society 25, 2, pp. 133-142, 139. 2006.

FRANKLIN, S. and ROBERTS, C. Born and Made. An Ethnography of Preimplantation Diagnosis. Princeton, 2006.

FULLWILEY, D. Race and genetics. Attempts to define the relationship. BioSocieties. 2, pp. 221-237. 2007.

GIBBON, S. Genomics as public health? Community genetics and the challenge of personalised med-icine in Cuba. In: S. Gibbon and S. Reynolds Whyte (eds.), Anthropology and Medicine Special Issue. Biomedical Technology and Health Inequities in the Global North and South. 16, 2, pp. 131-147. 2009.

Breast Cancer Genes and the Gendering of Knowledge. Science and Citizenship in the Cultural Context of the 'New' Genetics. London, 2007.

GIBBON, S.; NOVAS C., Biosocialities, Genetics and the Social Sciences. Making Biologies and Identities. London, 2008. 
GIBBON, S., et al. (eds.), Breast Cancer Gene Research and Medical Practices. Transnational perspectives in the time of BRCA. London, 2014.

GIBBON, S., JOSEPH, G., KALENDER, U., KAMPRIANI, E. et al. (eds.). Special Section: Perspectives on Globalizing Genomics. The case of 'BRCA' breast cancer research and medical practice. Journal of Biosocieties. 5, pp. 407-414. 2010.

GIBBON, S., KAMPRIANI, E. and NIEDEN, A. zur. (eds.). BRCA patients in Cuba, Greece and Germany. Comparative perspectives on public health, the state and the partial reproduction of 'neo-liberal' subjects', Special Section: Perspectives on Globalizing Genomics. the case of 'BRCA' breast cancer research and medical practice. Journal of Biosocieties. 5, pp. 440- 466. 2010.

GORDON, D. It takes a Particular World to Produce and Enact BRCA Testing; The US had it, Italy had Another. In: Gibbon et al. (eds.), Breast Cancer Gene Research and Medical Practices. Transnational perspectives in the time of BRCA. London, 2014.

HALLOWELL, N. Doing the right thing. Genetic risk and responsibility. Sociology of Health \& IIIness. 21, pp. 597-621. 1999.

HALLOWELL, N. et al. Men's decision making about predictive BRCA1/2 testing. The role of the family. Journal of Genetic Counseling 14, 3, pp. 207-217. 2005.

HAPPE, E. Heredity, Gender and the Discourse of Ovarian Cancer. New Genetics and Society 25, 2, pp. 171-196. 2006.

. The Material Gene. Gender, Race and Heredity after the Human Genome Project. New York, 2013.

JASANOFF, S. States of Knowledge. The Co-production of Science and Social Order. London, 2006.

JOLIE, A. My Medical Choice. The New York Times, May 14, 2013.

JOSEPH, G. Genetics to the People. BRCA as public health and the Dissemination of Cancer Risk Knowledge. In: Gibbon et al. (eds.), Breast Cancer Gene Research and Medical Practices. Transnational perspectives in the time of BRCA. London, 2014. 
KAMPRIANI, E., Between religious philanthropy and individualized medicine. Situating inherited breast cancer in Greece. Biomedical Technology and Health Inequities in the Global North and South. Anthropology \& Medicine 16, pp. 165178. 2009.

KLAWITER, M. The biopolitics of breast cancer. Changing cultures of disease and activism. London, 2008.

LANDECKER, H. and PANOFSKY, A. From Social Structure to Gene Regulation and Back. A Critical Introduction to Environmental Epigenetics for Sociology. Annual Review of Sociology. 39, pp. 333-357. 2013.

LANDECKER, H., Food as exposure. Nutritional epigenetics and the new metabolism. Journal of Bioso-cieties. 6, pp. 167-94. 2011.

LEE, S. Empowerment and the Rendering of Biocapital in Direct to Consumer Personal Genomics. In: Gibbon et al. (eds.), Breast Cancer Gene Research and Medical Practices. Transnational perspectives in the time of BRCA. London, 2014

Racial realism and the discourse of responsibility for health disparities in a genomic age. In: B. Koenig, S.S.J. Lee and S. Richardson (eds.) Revisiting Race in a Genomic Age. New Brunswick - NY, pp. 342-357. 2008.

LEMKE, T. Beyond genetic discrimination. Problems and Perspectives of a contested notion. Genomics, Society and Policy 3, pp. 22-40. 2005.

LOCK, M. The lure of the epigenome. The Lancet. 381, pp. 9881, 1896-1897. 2013.

MACDONALD, A. Situating Breast Cancer Risk in Urban India. Gender, Temporality and Social Change. in: Gibbon et al. (eds.), Breast Cancer Gene Research and Medical Practices. Transnational perspectives in the time of BRCA. London, 2014.

MANSFIELD, B. Race and the new epigenetic biopolitics of environmental health. Biosocieties. 7, pp. 352-372. 2012. 
MONTOYA, M. Bioethnic conscription. Genes, race, and Mexicana/o ethnicity in diabetes research. Cultural Anthropology 22, pp. 94-128. 2007.

MOZERSKY, J. and GIBBON, S. Mapping Jewish Identities: migratory histories and the transnational re-framing of Ashkenazi BRCA mutations. In: Gibbon et al. (eds.), Breast Cancer Gene Research and Medical Practices. Transnational perspectives in the time of BRCA. London, 2014.

MOZERSKY, J. and JOSEPH, G. Case Studies in the Co-Production of Populations and Genetics. The Making of "at Risk" Populations in BRCA genetics. Biosocieties 5, 4, pp. 415-439. 2010.

NIEWÖHNER, J. Epigenetics. Embedded bodies and the molecularisation of biography and milieu. BioSocieties 6, 3, pp. 279-298. 2011.

PALFNER, S., Gen-Passagen. Molekularbiologische und medizinische Praktiken im Umgang mit Brustkrebs-Genen. Wissen - Technologie Diagnostik, Bielefeld, 2009.

PELTERS, B. Gender Trouble? Queering the Medical Normativity of BRCA Femininities. in: Gibbon et al. (eds.), Breast Cancer Gene Research and Medical Practices. Transnational perspectives in the time of BRCA. London, 2014.

RABINOW, P. Artificiality and Enlightenment; From Sociology to Biosociality. in: P. Rabinow (ed.), Essays on the anthropology of reason. Princeton, pp. 91-112. 1996.

RAPP, R. Testing women, testing the fetus. The social impact of amniocentesis. New York, 1999.

RUBIN, L. and MELO-MARTIN, I. de. Ethical Analysis of PGD for BRCA. Attending to more than risks and benefits. In: Gibbon et al. (eds.), Breast Cancer Gene Research and Medical Practices. Transnational perspectives in the time of BRCA. London, 2014.

SCHUNDLER, M. Historicizing Biomedicine toward a history of the present of BRCA. In S. Gibbon, G. Joseph, J. Mozersky et al. (eds.) Breast Cancer Gene Research and Medical Practices. Transnational perspectives in the time of BRCA London, 2014. 
STRATHERN, M. Reproducing the future. Anthropology, kinship and the new reproductive technologies. New York, 1992.

YATES-DOERR, E. Bodily betrayal. Love and anger in a time of epi-genetics. In: F. Mascia-Lees (ed.), A Companion to Anthropology of the Body and Embodiment. Malden - MA, 2011, pp. 292-306.

ZIMMERMAN, E. et al., The BRCA patent controversies. An international review of patient disputes. In: Gibbon et al. (eds.), Breast Cancer Gene Research and Medical Practices. Transnational perspectives in the time of BRCA. London, 2014.

\section{Artigo:}

Recebido em: 18/10/2014

Aceito em: 5/12/2014 